\title{
Research on Interactive Teaching Mode of College English Based on Modern Information Technology
}

\author{
Qiong Peng \\ School of Foreign Languages, Wuhan Textile University, Wuhan, 430073, China \\ Email: lily_hoo@126.com
}

Keywords: information technology; college English; interactive teaching; mode

\begin{abstract}
With the advent of the information age, the information technology represented by computer by computer and the Internet has been widely used in all fields of education. The information technology which can update the teaching methods and promote teacher-student interaction is essential to the college classroom. This paper taking the college English classroom as an example carries out the following researches: (1) comparing the difference between the interactive mode supported by the information technology and the traditional teaching; (2) exploring how the classroom interaction supported by the information technology goes on; (3) analyzing problems encountered in classroom interaction and the related factors affecting the interactive behavior of college English teaching.
\end{abstract}

\section{Introduction}

Compared with the use of foreign information technology in education, the information technology has not been used in our country in terms of education until the early 1980s. At that time, China only begun to adopt the computer-assisted teaching, which was 20 years longer than the United States. Since the 21st century, the reform and development of education have faced new challenges and opportunities, while the key to coping with challenges and seizing opportunities is how to effectively integrate information technology with teaching. According to the current investigation, though the interactive applications have received widespread attention, most of our scholars are only interested in the overall interactive technology applications and theories, while they ignore the interactive research in the classroom, not to mention the interaction of specialized disciplines. This indicates that the interactive research under the environment of information technology in our country still stays in the computer-aided teaching stage till now. However, in my view, although the media and tools used in teaching can be seen in everywhere, the most basic form of teaching in our country is classroom teaching. Therefore, no matter under what circumstances, interactive teaching in the classroom should be the primary issue for researchers, so we can not only focus on the convenience brought by information technology for "teaching", we should also pay attention to the significant meaning of information technology for "learning".

\section{Related Concept and Theory}

\subsection{The Concept of Information Technology}

In terms of technical level, the information technology refers to the acquiring, transmitting, processing, reproduction and application of information, including the four basic contents of sensing, communication, computer, artificial intelligence and control technology. This definition emphasizes the modernization and high-tech content of information technology. ${ }^{[1]}$ In terms of methodological level, the information technology primarily refers to science, technology and engineering training methods and management techniques used in information processing. The application of these methods and management techniques involves human-computer interactions and the corresponding society, economy and culture and many other things. The author holds that information technology mainly refers to the smart technology of processing, storage and 
transmission of texts, graphics and animations under the support of various information media. The information technology has been widely used in various fields, while in the field of education, the information technology mainly refers to the network and multimedia technology.

\subsection{The Concept of "Classroom interaction"}

The classroom interaction being the most basic activity in education is also an integral part of the teacher-student behavior at school. ${ }^{[2]}$ For teachers engaged in language, classroom interaction is a very important concept. Therefore, numerous education experts have their own interpretation of the interaction in the classroom.

According to The Longman Dictionary of Teaching and Applied Linguistics, interaction is a way of using language in a conversation and class interaction is a pattern of verbal and non-verbal communication, which can also be seen as one kind of social relationship in the classroom. "All Wright (1984) argues that classroom interaction is a face-to-face interaction between teacher and student. Listeners have the opportunity to ask questions to the speaker indicating their confusion and asking the speaker to explain or repeat the statement. These are the main features of interpersonal interaction. Therefore, the classroom interaction means the process of information exchange occurring between two or more participants. Zuo tian, Huang Fuquan (2011) argues that: "Classroom interaction" refers to the special interactions existing in the classroom, mainly including teacher-student and student-student interaction.

The classroom interaction in this paper refers to the exchange of information between teachers and students, students and students. ${ }^{[3]}$ The study in this paper is the narrowly defined interaction of college English classrooms, namely the interaction between students and students, students and students in college English classes.

\section{Survey of the Current Situation of College English Classroom Interaction Supported by the Information Technology}

\subsection{Research Design}

The author, choosing the English classroom of Wuhan Textile University as the research object, observes four main courses in English teaching respectively according to the classification of English teaching and the characteristics of the environment: listening course, oral course, reading course of college English. Two courses have been selected in every teaching form, six courses in total. The author adopts ITIAS to sample the data of three English courses in the college, in which a sample is collected every 5 seconds, and the corresponding interactive coding system is used to identify. [4] It becomes an ordered classroom coding library, and then two adjacent pairs of sequences are selected, and then we analyze the matrix of the previous data for the number of rows, the latter data for the number of columns counting once in the corresponding cell, thus the analysis matrix of classroom interactive behavior taking shape.

\subsection{Data processing}

According to the interactive analysis matrix of three courses, we have calculated the proportion of classroom interactive activities in three college English courses according to the ITIAS migration matrix analysis formula, as shown in Table 1 
Table 1 Statistics of Classroom Interactive Behavior (\%)

\begin{tabular}{|c|c|c|c|c|}
\hline Variable & Listening & Oral & Reading & Average \\
\hline $\begin{array}{c}\text { Teacher } \\
\text { Language }\end{array}$ & 14.15 & 63.08 & 22.86 & 33.36 \\
\hline $\begin{array}{c}\text { Student } \\
\text { Language }\end{array}$ & 12.46 & 19.86 & 17.7 & 16.67 \\
\hline $\begin{array}{c}\text { Class Silent } \\
\text { Rate }\end{array}$ & 0.4 & 12.56 & 0.99 & 0.91 \\
\hline $\begin{array}{l}\text { Percentage of } \\
\text { Student Who } \\
\text { Are Thinking in } \\
\text { Silence }\end{array}$ & 100 & 29.16 & 100 & 76.39 \\
\hline $\begin{array}{c}\text { Invalid } \\
\text { Language Ratio }\end{array}$ & 0 & 0 & 0 & 0 \\
\hline $\begin{array}{l}\text { Ratio of Indirect } \\
\text { Impact and } \\
\text { Direct Impact of } \\
\text { Teachers }\end{array}$ & 46.51 & 139.1 & 149.98 & 111.96 \\
\hline $\begin{array}{c}\text { Ratio of } \\
\text { Negative and } \\
\text { Positive Impact } \\
\text { of Teachers }\end{array}$ & 13.82 & 131 & 85.7 & 230.52 \\
\hline $\begin{array}{l}\text { Percentage of } \\
\text { Teachers' } \\
\text { Question } \\
\end{array}$ & 24.98 & 6.93 & 25.76 & 19.22 \\
\hline $\begin{array}{l}\text { Percentage of } \\
\text { Teachers’ } \\
\text { Opening } \\
\text { Question }\end{array}$ & 27.24 & 44. 37 & 35.37 & 35.66 \\
\hline $\begin{array}{l}\text { Percentage of } \\
\text { Teachers’ } \\
\text { Closed Question }\end{array}$ & 72.86 & 55.82 & 61.68 & 63.45 \\
\hline $\begin{array}{c}\text { Percentage of } \\
\text { Technology Use }\end{array}$ & 72.06 & 4.07 & 56.87 & 68.35 \\
\hline $\begin{array}{c}\text { Percentage of } \\
\text { Students' } \\
\text { Discussion } \\
\end{array}$ & 46.59 & 0 & 54.74 & 33.78 \\
\hline
\end{tabular}

\subsubsection{Classroom structure}

A complete classroom is composed of teacher language, student language, classroom silent rate, teachers' questions and students' discussions. According to Table 1, we can see that the proportion of teachers' language of listening is $14.15 \%$, which is the lowest proportion among the three courses. This shows that teachers do not spend too much time on speaking, but on the content presented by information technology. The highest proportion of oral language teachers is $63.08 \%$, and the student language ratio is the highest of the three courses because oral course is a colloquial class in a multimedia environment and teachers adopts the teacher-student interaction mode in order to allow students practicing speaking and correcting their pronunciation. The student language ratio of three courses is lower than Flanders' standard of $20 \%$ of the students in the traditional classroom and the lowest is the listening course. Overall, the average silent rate of the three classes is $0.91 \%$, of which $76.39 \%$ of the silent hour's students are thinking. This indicates that the utilization of the entire class is still quite high and there is no disorder and confusion, which means all teachers own better 
organizational control ability.

\subsubsection{Use of Information Technology}

From Table 1, we can see that the proportion of technology used in listening and reading course is very high in all three courses, which shows that information technology is an indispensable part in the college English classroom. [5] The proportion of technology used in oral course is relatively low because oral course is conducted under the multimedia environment. On the one hand, the oral course does not need to present educational content and achieves the teaching goal by stimulating students to speak English; on the other hand, there is only demonstration system in most multimedia environment and it is difficult for teachers to interact with students through technical operations. Among them, the highest proportion of the technology used in the listening reaches $72.06 \%$. The number of teachers using information technology to demonstrate teaching content is 268 times and the number of students to watch the media presentation is 158 times, which can be specifically demonstrated by that teachers use information technology to play listening materials and students carry out passive learning. The proportion of technology used in reading course is $56.87 \%$. Teachers reach 206 times of using information technology to demonstrate teaching content and students reaches 132 times of watching the media presentation. In general, as technology advances, information technology is gaining more prominence in college English classes. Although technology usage has increased, most teachers only use it as the tablet's alternatives instead of taking full use of the real advantage of information technology.

\section{Factors Affecting the Interactive Mode of College English Class}

\subsection{Teachers}

Teachers being an important part of the classroom play the leading role in the classroom, so their behavior, personality and language all influence the classroom interaction. More and more teachers have emerged as the operators of information technology replacing the traditional blackboard by the information technology, thus the knowledge on the textbooks simply has been passed to students. Three main reasons can be concluded: (1) Teachers lack the modern teaching concept. With the change of the times, the traditional view of teaching based mainly on teachers is no longer applicable to today's teaching, so we must constantly update our concepts to get ahead of the times. The main reason why classroom interaction is stagnant is teachers' weak knowledge of interaction, especially some older senior teachers. The author believes that as long as teachers can handle the relation between interaction and teaching, they can enable the interaction of the classroom to promote teaching, and for teachers they should have the ability to manage the classroom and organize activities. (2) Teachers have different personality traits. In general, quiet English teachers like lecture-based classroom interaction mode and they do not want to see the lively scene, only hoping students to quietly listen to their own lectures; lively English teachers prefer mixed-class interaction model and they will use a variety of teaching methods and means to stimulate students' desire to learn, making the whole class active; and friendly character English teachers prefer conversation-based interactive mode and they want students to grasp the language in an equal dialogue; those with steady personality prefer the practice-based classroom interaction. (3) Teacher's information literacy needs to be improved. It is because of the lack of such innovative ideas among the English teachers in the above courses that the advantages of information technology have not been brought into full play. They can recognize the importance of information technology in English classes, but they simply use information Technology to display the textbook content.

\subsection{Students}

From the above findings we can see that more than half of the students do not want to speak or speak negatively, which to some extent shows that students' interaction awareness in the college English classroom is not high and they are not willing to interact with teachers, nor willing to 
promptly help students to correct mistakes. In addition, students consider that self-fulfillment is also a major factor that motivates them to participate in the interaction. They try their best to learn more in the classroom, but in the language learning, there is no way to be more effective than the interaction, so they hope to interact with teachers and students, which drives them to actively participate in English class interaction. On the contrary, if students who do not love learning themselves, they will not have the desire to learn even though the teachers are strict with them and the activities themselves are meaningful. What's more, they will not actively participate in the interaction in the classroom. Finally, the class style can also affect classroom interactions.

\subsection{Content Factors}

English listening is becoming increasingly important in English teaching and examinations, so teachers have to carry out numerous listening training to improve their listening comprehension. Most of these listening materials are released by multimedia, so we can see that listening has a long T-behavior time, during which teachers will play some listening materials, and then ask students to answer relevant questions based on these listening materials. This can not only train students' listening ability, but also check students' learning results. The particularity of English listening materials determines the application of information technology in the classroom interaction, and teachers can effectively improve students' English listening ability through numerous training.

Generally speaking, the college oral English class is to train students' verbal ability in English, and a large amount of comprehensible output plays an important role in language acquisition. Therefore, the most important point of oral English teaching is to provide students more chances to practice oral English. The teachers ask the students questions on the textbooks and require them to answer in English, and then based on the students' answers implement comments and corrections, so "one by one" oral practice determines that the spoken language is a dialogue course.

Compared with other English courses, English reading class is not very demanding for students' verbal and listening ability. It examines English knowledge accumulation and text reading skills, so most English teachers ignore the interactive behavior in English reading class, turning it into teacher-based instructional courses. As information technology brings more and more convenience to education, teachers will not use the blackboard and language to display the teaching contents, but use information technology to teach more intuitively and vividly.

\section{Conclusion}

Abundant hardware devices will also offer teachers a lot of choices in designing interactive activities. Students can interact with teachers through computers, the Internet, interactive whiteboards and other devices, which can not only help students develop self-exploration ability but also improve their independent ability to learn. Through the extraction of information technology factors, this paper counts and analyzes factors influencing classroom interaction and summarizes the four factors that affect the enthusiasm of classroom interaction, namely, teacher, student and content factor. In addition, the elements in each factor based on the above analysis and the questions raised will also influence the interactive mode of College English class. We hope it will bring some reference for teachers to design and arrange teaching activities in the future in order to optimize the interactive mode of college English classroom and improve the efficiency of classroom teaching.

\section{References}

[1] Evaluation of different delivery modes of an interactive e-learning programme for teaching cultural diversity [J]. Kamila Hawthorne, Hayley Prout, Paul Kinnersley, Helen Houston. Patient Education and Counseling. 2008(1)

[2] Understanding family, social and health experience patterns in British Bangladeshi families: are people as diverse as they seem?[J]. Kamila Hawthorne, Rosin Pill, Jasmin Chowdhury, Lindsay Prior. Primary Health Care Research \& Development. 2007(4) 
[3] Evaluation of different delivery modes of an interactive e-learning programme for teaching cultural diversity [J]. Kamila Hawthorne, Hayley Prout, Paul Kinnersley, Helen Houston. Patient Education and Counseling. 2008(1)

[4] Classroom Organization and Participation: College Students’ Perceptions [J]. Robert R., Weaver, Jiang. Qi. The Journal of Higher Education. 2005 (5)

[5] Learning through interaction: the study of language development. Wells G,et al. . 1981 